set oscillating the block executes movements the amplitudes and periods of which diminish in such a way that resonance effects are prevented. By experimenting on a movable platform, Galitzin found that the acceleration of the enforced movement was the determining factor in the overthrow of each block.

Prof. Reid, of Baltimore, described a new method of estimating the intensity of an earthquake, the fundamental proposition being that the energy associated with an earthquake was proportional to the square of the area within a given isoseismal line.

Mr. Napier Denison, of Victoria, Vancouver, gave an account of his observations of secular movements of the horizontal pendulum, and made a strong claim for Victoria as a place well fitted for seismological work.

Prof. Omori, of Tokyo, described some of the recent volcanic and seismic phenomena of Japan, the most interesting being the rise of a new hill during the eruption of Usu-san in Hokkaido, and the increasing activity of Asama Yama, a volcano in the centre of Japan which rises to a height of 8000 feet. The dull red contents of the crater have been steadily rising in level for some time, and fairly large blocks of stone have been projected from it. A station has been built on the flank of the mountain, and seismographs installed in it. The character of the tremors is markedly different according as they do or do not accompany a volcanic eruption.

In their less strenuous moments the delegates and their friends enjoyed to the full the hospitality of Manchester, more especially the Lord Mayor's reception in the Town Hall; Prof. Schuster's garden-party at Kent House, when a remarkably good photograph was taken of all attending the congress; and the closing dinner given by the University Council, when Prince Galitzin, in a humorous impromptu speech, proposed the health of Prof. John Milne, whose characteristic reply was a fitting close to a great conference.

\section{THE MIGRATION OF A RACE. ${ }^{1}$}

THE theory of a relationship between the numerous languages spoken in the islands of the Indo-Pacific Ocean from Madagascar and Sumatra to the Philippines, and thence far eastward to Melanesia and Polynesia is almost universally accepted. But the connection of these languages with the Asiatic Continent, their origin, and the means by which they reached their present settlements, are still uncertain.

In the volume before us $\mathrm{Mr}$. Churchill essays to trace the migration of the Polynesian people from their first home on the borders of Indonesia, through Melanesia, to Nuclear Polynesia, that is, to the region round about Samoa, Tonga, and Niue. Dealing with the languages only, he recognises two streams of voyagers who have left traces of their passage in the loan words adopted from their speech by the Melanesians with whom they came in contact; these words being most numerous in the languages of the islands along the coasts of which the Polynesians passed, and less frequent in the languages more remote from their route.

One stream of these primitive Polynesians, or ProtoSamoans, passed north of New Guinea, bv way of the Admiralty, Bismarck, Solomon, and Santa Cruz Archipelagoes to Samoa. Another stream came southward through Torres Straits, by the south-eastern shores of Papua, through the New Hebrides to Fiji. In Nuclear Polynesia the two streams resumed their ancient fellowship, and thence despatched colonies to Hawaii, New Zealand, and the Far Eastern Pacific.

Later, there came upon these Proto-Samoans a swarm of kindred people whose origin and migrations Mr. Churchill regards as indefinite and obscure, and to whom he gives the name-Tongafiti- by which they are known in Samoan history. The Tongatiti are considered to have left no definite trace of a passage through Melanesia, though their presence in Nuclear Polynesia is clearly evident. The

"The Polynesian Wanderings." Tracks of the Migration deduced from an Examination of the Proto-Samnan Content of Efaté and other Languages of Melanesia. By W. Churchill. Pp. ix +5 I6. (Washington: Carnegie institution, rgrr.)

No. $2 \times 80$, VOL. 87$]$ origin and migrations of the Tongafiti are not discussed in the present volume.

In his earlier chapters the author devotes some attention to the two most prominent theories yet put forth as to the settlement of the Oceanic peoples, namely, those of Dr. Macdonald and Dr. Thilenius. The former refers the island races to an immigration from Arabia, and affirms their languages to be modern representatives of a Semitic tongue ( $c f$. NAture, March 19, 1908, p. 460). The latter regards the Polynesians as entrants into the Pacific by way of the Micronesian Islands, and sees in the Melanesian Islands, and the Polynesian settlements bordering them, the meshes of a net which has caught the drift of castaways blown westward from their homes in Eastern Polynesia. In his second chapter and elsewhere in his bools $\mathrm{Mr}$. Churchill utterly demolishes the Semitic theory of Macdonald, mainly on the grounds of illogical and forced etymologies, and perverted definitions of woŕds. Mr. Churchill finds difficulties and fallacies in the argument of Thilenius, chiefly with regard to the ascription of feeble navigating powers to the Polynesians, and to the unlikely survival of castaways among an anthropophagous people.

$\mathrm{Mr}$. Churchill regards the Proto-Samoans as a seafaring race, who, driven by some expulsive force, set out from Indonesia in double canoes. The principal difficulty in their navigation was the victualling of their vessels, and this led to coasting voyages wherever there were coasts to follow. When supplies ran short, a food colony was established on a suitable island until a sufficient crop was raised to carry the voyagers farther on. For these food colonies there were three requisites-a sufficient water supply, an encouraging area of soil for tilth, and an autochthonous population insufficient in number, or too weak, to prevent the settlement of strangers. Mr. Churchill considers the eastward impulse to have ceased in Bismarck Archipelago and Torres Straits, so that the crop settlements tended to become, in suitable places, permanent colonies. Also, as the fleet kept to windward in the seas along which they passed, the lands which became fixed settlements (as, e.g. Nuguria, Liueniua, Sikayana, Aniwa, and Futuna) would be found on the windward side of the archipelago with which they are associated. The apparent exceptions, Rennel and Bellona, though leeward of the Solomons, are, however, on the weather side of the voyagers in the southern stream.

Mr. Churchill bases his evidence of this migration upon an examination of the Polynesian words contained in the languages of the Solomon and New Hebrides islands. From comparisons of the material available to him, which are given in an appendix on data and notes, and the Polynesian content therein, set forth in a series of elaborate tables, the author deduces the amount of likeness shown by the individual languages to Polynesia. His method in the comparisons is sound and accurate, and a very welcome contrast to the wild guesses of some writers on the subject. But the deficiencies and imperfections of his material are a source of serious error. For a proper estimate of Polynesian likeness the vocabularies compared should be of equal size and range of signification, else the presence or absence of certain words would unduly exaggerate or diminish the likeness. Mr. Churchill's tables show this. He gives the coefficient of likeness to Polynesian of Belaga as roo, whilst Nggela, of which Belaga is a dialect, is given only 8o. So also the likeness of Nguna to Polynesian is expressed by 93 , whilst that of Sesake (the same language, Sesake being a colony from Nguna) is only 76 .

$\mathrm{Mr}$. Churchill makes no comparisons of grammar. All the Polynesian words present in Melanesia are regarded as loans, but if this is so, it is remarkable that many of the languages have borrowed 80 or 90 per cent. of Polynesian vocables without borrowing a single grammatical form In some cases, not pointed out by Mr. Churchill, grammatical forms which survive in Polynesian have been preserved more fully in Melanesian languages which are not on the supposed migration route.

The backward track deduced by $\mathrm{Mr}$. Churchill breaks off short at Moanus (Admiralty Island) in the north, and at Motu (New Guinea) in the south, and he leaves the starting point of the Proto-Samoans in a waste of empty sea, where non-Polynesian and non-Melanesian languages occupy the whole seaboard. He states that "only a few of 
the vocables in Melanesia for which we have discovered Polynesian affinities are found to carry that affinity back to Indonesia." $\mathrm{He}$ is "ready to pronounce the decree of Divorce upon Malay and Polynesian." Other judges of Indonesian will scarcely concur in this judgment.

It is impossible in the limits of this notice to give an adequate exposition of the value of Mr. Churchill's book to the student of Oceanic linguistics and ethnology. It is not only suggestive of points for discussion, but provides also material upon which the argument may be based. There is a bibliographical appendix, two maps, and a useful index. SIDNEY H. RAY.

\section{SCIENTIFIC PROGRESS IN THE UNIVERSITY OF OXFORD.}

THE annual report of the delegates of the University Museum, lately published, contains a very complete record of the scientific work done in the several depart. ments of the museum during the year 1910. In the department of physiology, special attention is directed to the establishment of an advanced practical course in physiological optics, under the direction of Prof. Gotch and Dr. Burch. A considerable amount of the requisite apparatus was made in the laboratory workshop. Prof. Arthur Thomson (human anatomy) announces that instruction in physical anthropology has now been systematically organised. The report of the Linacre professor of comparative anatomy (Prof. Bourne) also shows much evidence of steady progress. The list of additions to the collection is a long one, and numerous important memoirs have been published by members of the department during the past year.

Prof. Poulton submits a lengthy and interesting account of the work done in the rooms assigned to the Hope professor of zoology. A very fine collection and library of Oriental and British entomology, chiefly Hymenoptera, was presented by Mr. G. A. James Rothney; and other important accessions were received from numerous donors, among whom were $\mathrm{Mr}$. Herbert Druce, Commander J. J. Walker, Mr. J. H. Watson, Mr. S. A. Neave, Mr. W. A. Lamborn, and the Hon. Walter Rothschild. Special attention is directed to bred specimens received from Mr. A. D. Millar, of Durban, which prove that the conclusion tentatively arrived at by Mr. G. A. K. Marshall in 1902, that Euralia mima and $E$. wahlbergi are dimorphic forms of the same species, is in accordance with the fact. The collection of British Rhynchota, Hemiptera, and Homoptera belonging to the late Edward Saunders, and presented by the professor and Dr. G. B. Longstaff, is described as one of the most important additions ever made to the British collection in the department. Among the original memoirs published by workers in the department are Mr. H. Eltringham's important monograph on African mimetic butterflies and Mr. R. Shelford's contributions to the Genera Insectorum.

Noteworthy additions have been made to the anthropological collections contained in the Pitt-Rivers Museum. The energy of the curator, Mr. H. Balfour, who has paid three special visits to the Victoria Falls of the Zambezi, has resulted in the acquisition of a far more complete collection representing the archæology of that region than exists anywhere else. Other important accessions have come in from the Belgian Congo, British East Africa, West Africa, the Dordogne, and the Isle of Wight. In the department of experimental philosophy, Prof. Clifton reports that an extension of the laboratory is absolutely necessary, the only alternative being to restrict the number of students.

The report of the Wykeham professor of physics (Prof. Townsend) records the transference of the laboratory furniture and apparatus from the temporary quarters in the old museum to the fine new building provided by the senerosity of the Drapers' Company. The new premises have been found to be excellently adapted for giving practical instruction, and also for research work. In the department of chemistry, Prof. Odling notes the starting of a new course of advanced practical organic chemistry under Dr. Chattaway, and the publication of several important memoirs dealing with researches conducted in the chemical laboratory. These include Dr. Chattaway's work on chlorine, Mr. Marsh's on the solution of haloid double salts in organic solvents and on the halogen derivatives of camphor, and also the investigations by $\mathrm{Mr}$. Lambert and his pupils on the wet oxidation of metals. The report mentions that as a result of the work still in progress, it is hoped later to establish sufficient facts to warrant putting forward a modification of the present views on the subject of the corrosion of metallic iron.

A valuable consignment of rocks and fossils has been sent to the geological department from Peru, where $\mathrm{Mr}$. $\mathrm{J}$. A. Douglas is engaged in using the excellent opportunities for geological study now being afforded by several important railway cuttings. The expenses of the investigation are being borne by Mr, W. E. Balston, University College, and the consignment that has been already received is the first of many that may be expected as a result of Mr. Douglas's labours. Besides the usual field-work conducted by Prof. Sollas in the country about Oxford, an excursion, attended by sixteen students, was made to the Siebengebirge and the Eifel. Much work has been done by Miss Byrne and others on the rearrangement of the collections. A long series of specimens illustrating the history of the pleistocene epoch is in course of arrangement, and the work is rapidly approaching completion.

Like other heads of departments, the professor of rural economy (Prof. Somerville) finds himself somewhat embarrassed for want of room. The laboratories of botany and chemistry included in his department have been taxed to their utmost capacity to provide accommodation for the students. For the needs of the department of mineralogy, provision has been made by the allotment of a portion of the northern room of the old Radcliffe library, lately occupied by the Wykeham professor of physics. Many additions are recorded to the collections of specimens and the stock of apparatus, and some important researches have been carried on by Prof. Bowman, his pupils, and assistants.

A remarkable feature in many of the departmental reports that have now been briefly noticed, is the great and growing need of still further accommodation if the requirements of both teachers and students are to be satisfactorily met. Much has already been done; all departments alike tell the same tale of great and increasing activity in scientific work. Much still remains to do; but the document before us gives good hope for the future, for it contains abundant evidence that the ancient University of Oxford is becoming more and more alive to its responsibilities in the matter of scientific progress, as regards both teaching and research.

\section{ADVANCES IN REPTILIAN PALAONTOLOGY.}

IN the July number of The American Naturalist $\mathrm{Dr}$

O. P. Hay reopens the discussion with regard to the position of the limbs in Diplodocus and other sauropod dinosaurs, criticising the views of those who assert that these reptiles carried themselves in elephantine fashion, and maintaining his own opinion that the general pose was more after the crocodilian style. In regard to what may be called the elephant pose, it is pointed out that since a straight femur appears to have characterised the Proboscidea from the beginning, its occurrence in the modern representatives of the group may be regarded as a primitive feature, rather than an adaptation to the support of great bodily weight. At the conclusion of his arguments with regard to the pose of the sauropods, Mr. Hay expresses doubts as to whether the erect bird-like posture attributed to the carnivorous dinosaurs of the Jurassic is really true to nature. "The extraordinary development of the pubic bones of Aristosaurus, the expanded and anky. losed distal ends of which reached nearly half-way to the forelegs, seems to me to indicate that these animals, when in repose, had a prone position, resting much of the weight on the pubes, and that when running their legs straddled considerably.'

In reference to the opinion of Dr. Matthew that Sauropods were too bulky to have lived on land, it is added that "the law to which he gives expression does, of course, prescribe a limit to the size an animal can attain, but who has yet determined what that limit is?"

To vol. vii., part 4, of the Annals of the S. African พั. 2 I8O, VOL. 87] 